\title{
Bioaesthetics and regenerative medicine
}

"With the constant upping of healthcare demands owing to ever-increasing health and longevity expectations, today's bioaesthetic products are very likely to be tomorrow's healthcare therapies."

Bioaesthetics are defined as regenerative medicine-like therapies aimed at cosmesis rather than traditional medical ailments [1]. Regenerative Medicine from its very beginning has supported all areas of regenerative medicine including bioaesthetics [2-7]. Indeed, in the very first issue, the interview with Paul Kemp (Founder, Intercytex) highlighted the market for aesthetic regenerative medicine therapies and identified potential strategic partners not as big Pharma, but cosmetic companies [2]. Cosmetic companies are not newcomers to our sector; for example, for over a decade, L'Oreal has been using tissueengineered skin for safety evaluation of its products [101], initially purchasing EpiSkin in 1997 and more recently SkinEthic Laboratories [8]. This issue of Regenerative Medicine continues our long tradition of publishing the very best in bioaesthetic papers with a research paper by Jizeng Qiao et al. (Intercytex) [9], suggesting further evidence of the feasibility of cell therapy for hair loss and a highly comprehensive review by George Huang (Columbia University, NY, USA) [10] on the current state of tooth pulp and dentin regeneration. The loss of hair and teeth are of course not life-threatening conditions, however, in terms of quality of life, for a great many people they are both highly important. In the Western World, long gone are the days of false teeth, glass eyes and wigs being the norm, as so brilliantly depicted in the 1825 lithograph after Louis-Léopold Boilly 'Les Epiux Assortis' with the elderly couple removing their various false appendages [102]. Today, there is no clear line between cosmetic and health indications. For example, hair loss in women (female diffuse alopecia), keloid scars, acne scaring, receding gums (gingival recession) and adipose tissue wasting (lipodystropy) secondary to HIV therapy are all now universally agreed to be medical conditions warranting treatment. For these patients, in addition to their loss of physical appearance, there is also the potential for significant psychological morbidity. However, self-image is increasingly important to all of us, not just patients with underlying pathology.

Bioaesthetics has many hats and disguises including medical aesthetics, cosmetic surgery, rejuvenative therapy and cosmetic medicine. The origins are obscure; the results personally, socially and economically are not. The roots of cosmetic medicine can be traced back to the ancient Egyptian, Hippocratic, Roman and Byzantine physicians [11]. Galen of Pergamum, the eminent second century physician, philosopher and writer, described many cosmetic preparations used for the restoration of the physical appearance due to an underlying medical condition, for example, alopecia. Interestingly, Galen distinguished between cultivating acquired artificial beauty and cosmetic medicine, which has the goal of maintaining the natural beauty of a person or the physical restoration of the body [11]. Modern aesthetic medicine has its origins in the 1980 s, with the emergence of viable medical procedures for aesthetic and cosmetic indications, for example, collagen injections for wrinkles $[12,13]$. More recently botulinum toxin type A [14] for cosmetic purposes is the most popular therapy approved for the temporary treatment of moderate-to-severe frown lines in adults. This paradigm shift from conventional plastic surgery has led to a great many surgeons giving up their scalpels and switching to injectable therapies [13]. A move greatly demanded and approved by their patients. People today want to both function normally plus look the part, regenerative medicine therefore needs to continue to cultivate a holistic approach.

Whilst there is no doubt a great potential for charlatans and quackery, there is also the phenomenal opportunity to produce safe, effective and affordable bioaesthetic therapies. The broad categories are: cell-based therapies,

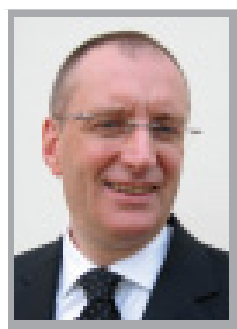

Chris Mason

Author for correspondence:

Advanced Centre for

Biochemical Engineering,

University College London,

Roberts Building, Torrington

Place, London, WC1E 7JE, UK

Tel.: +44 2076790140 ;

Fax: +44 2072090703

chris.mason@ucl.ac.uk

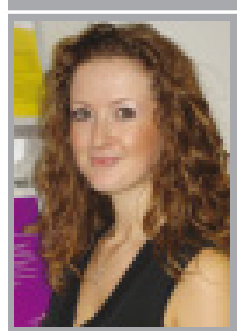

Elisa Manzotti

Future Medicine Ltd,

Unitec House, 2 Albert Place,

Finchley Central, London,

N3 1QB, UK

Tel.: +44 2083492033

Fax: +44 208343 2313;

e.manzotti@

futuremedicine.com;

www.futuremedicine.com

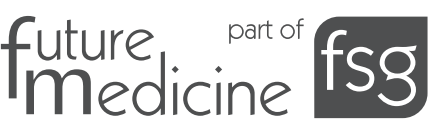


cell-produced extracellular matrix and cellconditioned media - all these approaches are presently already deployed in a very wide range of regenerative medicine activities [15-17]. The key issue is that just like any other area of regenerative medicine, bioaesthetics must be rigorously proven to both safe and effective. This requires scientific rational, unequivocal animal data and robust manufacture. It is therefore crucial to see the companies involved in bioaesthetics, such as Intercytex, Isolagen, Organogenesis and Renovo, all taking the appropriate level of responsibility, albeit at great cost in terms of time and resources. For example, all have potential bioaesthetic therapies undergoing rigorously controlled clinical trials. The results of these studies, in the same way as their therapeutic counterparts, yield highquality peer-reviewed publications that further add to the common pool of regen knowledge [18]. Furthermore, even when approved by the regulators, these therapies will require trained clinicians to prescribe them. Likewise, the ethical issues surrounding aesthetic medicine are paramount and must never be forgotten [19], nor too the fact that no therapy can ever be $100 \%$ without complications - even injectable fillers, which are considered to be very safe, such as hyaluronic acid, have adverse reactions [20].

Why should the regenerative medicine sector be interested in bioaesthetics? The answer is the growing demand for these therapies, for example, during 2008, 5 million doses of Botox ${ }^{\circledR}$ (botulinum toxin type A) were injected at an average cost of $\$ 500$ [103]. The principal drivers for bioaesthetics include [104]:

- Aging of the baby boomer population (over 75 million Americans were born between 1946 and 1960);

- The desire of many individuals to retain or even improve their physical appearance;

- The impact of managed care and reimbursement policies on physician economics, particularly in the USA, which has motivated physicians to establish or expand the menu of elective private-pay aesthetic procedures that they offer;

- Broadening base of the practitioners performing cosmetic procedures beyond dermatologists and plastic surgeons to nontraditional providers.

In addition, lessons learnt in the clinical and commercial translation of bioaesthetic therapies are directly applicable to regenerative medicine in general. These considerable knock-on effects are of great benefit in accelerating the advancement of the fledgling industry. It is interesting to note that the massive value of the cosmetic medicine market has not gone unnoticed by the politicians. For example, US Senator Max Baucas, the Chairman of the Senate Finance Committee, is widely credited for toying with the idea of a cosmetic surgery tax in order to help fund Obama's healthcare reforms [103].

\section{"Why should the regenerative medicine sector be interested in bioaesthetics? The answer is the growing demand for these therapies..."}

An additional healthcare benefit is the potential to use established bioaesthetic products for medical conditions that it would be uneconomic to develop therapies for in isolation. For example, Intercytex is exploring the use of their skin repair and rejuvenation product, Vavelta ${ }^{\circledR}$ (a suspension of dermal fibroblasts) for the therapy of epidermolysis bullosa. Epidermolysis bullosa is a rare genetic disorder characterized by extremely fragile skin and recurrent blister formation resulting from minor mechanical friction or trauma that ranges in severity from mild to severely disabling and life-threatening [105]. This potential for crossover must not be forgotten.

Overall, the challenges to produce bioaesthetics are no less demanding than for lifesaving therapies. Indeed, the regulators and the public may be even more exacting with respect to the risk-to-benefit ratio given the nature of the final product. With the constant upping of healthcare demands owing to ever-increasing health and longevity expectations, today's bioaesthetic products are very likely to be tomorrow's healthcare therapies. All are welcome under the regenerative medicine umbrella provided the therapies replace or regenerate human cells, tissue or organs, to restore or establish normal function [21]. The big question is: 'What defines normal?'

\section{Financial \& competing interests disclosure}

The authors have no relevant affiliations or financial involvement with any organization or entity with a financial interest in or financial conflict with the subject matter or materials discussed in the manuscript. This includes employment, consultancies, honoraria, stock ownership or options, expert testimony, grants or patents received or pending, or royalties.

No writing assistance was utilized in the production of this manuscript. 


\section{Bibliography}

1 Regenerative medicine glossary. Regen. Med. 4(Suppl. 4), S1-S88 (2009).

2 Kemp P: Cell therapy: back on the up-curve. Interview with Paul Kemp by Elisa Manzotti. Regen. Med. 1(1), 9-14 (2006).

3 MacKay G: Bioactive wound healing, bioaesthetics and biosurgery: three pillars of product development. Interview with Geoff MacKay. Regen. Med. 1(2), 169-174 (2006).

4 Cherubino M, Marra KG: Adipose-derived stem cells for soft tissue reconstruction. Regen. Med. 4(1), 109-117 (2009).

5 Qiao J, Turetsky A, Kemp P, Teumer J: Hair morphogenesis in vitro: formation of hair structures suitable for implantation. Regen. Med. 3(5), 683-692 (2008).

6 Yoshimura K, Suga H, Eto H: Adiposederived stem/progenitor cells: roles in adipose tissue remodeling and potential use for soft tissue augmentation. Regen. Med. 4(2), 265-273 (2009).

7 Mason C: Regenerative medicine 2.0. Regen. Med. 2(1), 11-18 (2007).

8 MacNeil S: Progress and opportunities for tissue-engineered skin. Nature 445(7130), 874-880 (2007).

9 Qiao J, Zawadzka A, Philips E et al.: Hair follicle neogenesis induced by cultured human scalp dermal papilla cells. Regen. Med. 4(5), 667-676 (2009).

10 Huang T: Pulp and dentin tissue engineering and regeneration: current progress. Regen. Med. 4(5), 697-707 (2009).
11 Lascaratos J, Tsiamis C, Lascaratos G, Stavrianeas NG: The roots of cosmetic medicine: hair cosmetics in Byzantine times (AD 324-1453). Int. J. Dermatol. 43(5), 397-401 (2004).

12 Tromovitch TA, Stegman SJ, Glogau RG: Zyderm collagen: implantation technics. J. Am. Acad. Dermatol. 10 (2 Pt 1), 273-278 (1984).

13 Legrand JJ: Aesthetic medicine: a booming medical activity. J. Cosmet. Dermatol. 2(1), 1 (2003).

14 Carruthers A, Carruthers J: History of the cosmetic use of Botulinum A exotoxin. Dermatol. Surg. 24(11), 1168-1170 (1998).

15 Notara M, Daniels JT: Biological principals and clinical potentials of limbal epithelial stem cells. Cell Tissue Res. 331(1), 135-143 (2008).

16 Langer A, Rogowski W: Systematic review of economic evaluations of human cell-derived wound care products for the treatment of venous leg and diabetic foot ulcers. BMC Health Serv. Res. 9, 115 (2009).

17 Timmers L, Lim SK, Arslan F et al.: Reduction of myocardial infarct size by human mesenchymal stem cell conditioned medium. Stem Cell Res. 1(2), 129-137 (2007).

18 Ferguson MW, Duncan J, Bond J et al.: Prophylactic administration of avotermin for improvement of skin scarring: three double-blind, placebo-controlled, Phase I/II studies. Lancet 373(9671), 1264-1274 (2009).

19 Smith SP Jr, Williams EF 3rd: The delivery of aesthetic medicine: illegal or not? Facial Plast. Surg. Clin. North Am. 15(2), 265-271, viii (2007).
20 Zielke H, Wolber L, Wiest L, Rzany B: Risk profiles of different injectable fillers: results from the Injectable Filler Safety Study (IFS Study). Dermatol. Surg. 34(3):326-35; discussion 35 (2008).

21 Mason C, Dunnill P: A brief definition of regenerative medicine. Regen. Med. 3(1), 1-5 (2008).

\section{Websites}

101 L'Oreal Invitroskin. www.invitroskin.com

102 Wellcome Library, London. L0021862 1825 lithograph after Louis-Léopold Boilly 'Les épiux assortis'.

http://images.wellcome.ac.uk

103 Spillius A: Cosmetic surgery tax proposed to finance care reform. Telegraph.co.uk 28th July 2009.

www.telegraph.co.uk/news/worldnews/ northamerica/usa/5926948/Cosmeticsurgery-tax-proposed-to-finance-health-carereform.html

104 Isolagen Inc, United States Securities and Exchange Commission Form 10-K 15th April 2009.

http://ccbn.10kwizard.com/cgi/convert/pdf/ ISOLAGENINC10K.

pdf?ipage $=6267162 \&$ num $=-2 \&$ pdf $=1 \& \mathrm{xml}=$ $1 \&$ cik $=357097 \&$ odef $=8 \&$ rid $=12 \&$ quest $=1 \&$ $\mathrm{xbrl}=0 \& \mathrm{dn}=2 \& \mathrm{dn}=3$

105 Epidermolysis Bullosa Medical Research Foundation. www.ebkids.org/index.php 